Journal of Biotechnology and Strategic Health Research

\author{
Research Article / Araştırma Makalesi
}

http://dergipark.org.tr/tr/pub/bshr

\title{
Ordu İlinde Bruselloz Sıklığının Araştırılması: Beş Yıllık Değerlendirme
}

\author{
Investigation of Brucellosis Seroprevalence in Ordu City: Five-Years Review
}

(iD) Arzu Altunçekiç Yıldırım", Yeliz Çetinkol ${ }^{2}$

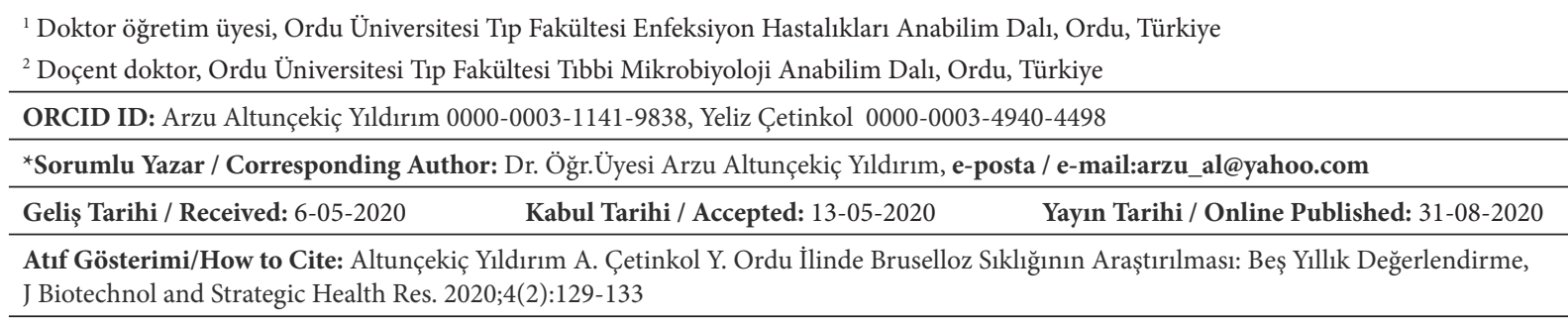

Özet

Amaç Bruselloz tüm dünyada yaygın olarak görülen ve halk sağlığı açısından problem yaratmaya devam eden bir zoonozdur. Görülme sıklığı ülkelerin gelişmişlik düzeyleri ile ters orantılıdır. Gelişmekte olan ülkelerde ciddi veri eksikliklerine rağmen varlığını endemik şekilde sürdürdüğü görülmektedir. Ülkemizde yapılan seroprevalans çalışmaları bruselloz oranını \%1,3 ile \%26,7 arasında bildirmektedir. Bu çalışmada Ordu ilinde bruselloz sıklığına yönelik herhangi bir veri olmadığından ilimizdeki durumun değerlendirilmesi amaçlanmıştır.

Materyal ve 2014-2018 yılları arasında Ordu Üniversitesi Tip Fakültesi Hastanesi poliklinik ve servis hastalarından bruselloz şüphesiyle

Metod alınarak laboratuvarımıza gönderilen 2500 serum örneği retrospektif olarak değerlendirilmiştir. Tanı amacıyla Rose Bengal testi ve Coombs aglütinasyon testi kullanılmıştır. Coombs aglütinasyon testi 1/320 ve üzeri ise anlamlı kabul edilmiştir.

Bulgular Bruselloz ön tanısı ile değerlendirilen 2500 örneğin 375’inde (\%15) Rose Bengal testi pozitif saptanmıştır. Örneklerin 305 'inde (\%12) ise Coombs aglütinasyon testi anlamlı değer olan 1/320 ve üzerinde pozitif bulunmuştur. Değerlendirilen yıllar içerisinde en düşük pozitiflik oranı 2016 yılında \%6,3 saptanırken 2018 yllında \%18 olarak gözlenmiştir.

Sonuç Bruselloz ülkemizde endemik bir zoonotik hastalık olup ilimizde pek çok ile göre daha yüksek oranlar söz konusudur. Klinik yakınmaların uyumlu olduğu hastalarda tanıda akılda tutulmalıdır. Sonuçlarımız hayvancllık ve süt ürünleri üretimi faaliyetlerinin yoğun olduğu Ordu ilinden bildirilen ilk verilerdir.

Anahtar Ordu; bruselloz; seroprevalans

kelimeler

Abstract

Aim Brucellosis is a zoonosis that is widespread all over the world and continues to be a major problem in terms of public health. Seroprevalence is inversely proportional to the level of development of the countries. Despite the lack of serious data in developing countries, it seems that they continue their existence endemically. Seroprevalence studies in our country report the rate of brucellosis between $1.3 \%$ and $26.7 \%$. Since there is no data on the frequency of brucellosis in the province of Ordu, it is aimed to evaluate the situation in our province.

Material and In this study, conducted between 2014 and 2018 in Ordu University Medical Faculty Hospitals with the prediagnosis of brucellosis sent from Method outpatient clinics and services, the serum results of 2500 patients were evaluated retrospectively. For diagnosis, Rose Bengal test and Coombs agglutination test were used. Coombs agglutination test was considered to be significant at 1/320 and above.

Results Of the 2500 samples evaluated with brucellosis pre-diagnosis, 375 (15\%) Rose Bengal test was positive. In 305 (12\%) of the samples Coombs agglutination test was found to have a positive value of $1 / 320$ and above. The lowest rate was $6.3 \%$ in 2016 and $18 \%$ in 2018 .

Conclusion Brucellosis, which is an endemic zoonosis in our country, has been detected in higher rates in our province compared to many others. Therefore, the diagnosis should be kept in mind in patients with compatible clinical complaints. Our results are the first data reported from Ordu province where livestock and dairy products activities are intense.

Key words Ordu; brucellosis; seroprevalence 


\section{GIIRIŞ}

Bruselloz tüm dünyada yaygın olarak görülen ve halk sağlığı açısından önemli problem yaratmaya devam eden bir zoonozdur. Görülme sıklığı ülkelerin gelişmişlik düzeyleri ile ters orantılıdır. İnsanlara bulaş üç önemli yol ile gerçekleşebilir. ${ }^{1}$ Kontamine et veya süt-süt ürünlerinin sindirim yolu ile alınması, enfeksiyöz aerosellerin inhalasyonu, enfekte hayvan kan veya dokuları ile bütünlüğü bozulmuş deri veya konjonktival temas bulaş yolları olarak sıralanabilir. Dolayısıyla hayvancılık ile uğraşanlar, veteriner hekimler, mezbaha işçileri, et sanayisinde çalışanlar hastalığın görülme sıklığı açısından risk altındadır. Aynı zamanda laboratuvar kaynaklı bulaş da görülebildiğinden laboratuvar çalışanları da bu riskli grup içerisinde bulunmaktadır. ${ }^{2}$ İnsanlarda yaptığı hastalığın yanı sıra hayvanlarda da üreme kaybına neden olarak önemli iş gücü ve ekonomik kayıplara yol açabilmektedir. Gelişmekte olan ülkelerde ciddi veri eksikliklerine rağmen varlığını endemik şekilde sürdürdüğü görülmektedir. ${ }^{3}$ Ülkemizde yapılan seroprevalans çalışmaları bruselloz oranını \%1,3 ile 26,7 arasında bildirmektedir. ${ }^{4}$ Yüksek oranlar daha çok Güneydoğu Anadolu illerinden bildirilse de hastalık ülkemizde pek çok bölgede endemik olmaya devam etmektedir. Karadeniz Bölgesi ve Ordu ili hayvancılık faaliyetlerinin yoğun olduğu ve brusellozun görüldüğ̈u yerler olmakla birlikte daha önce bildirilmiş veri söz konusu değildir. Çalışmamızda 20142018 yılları arasında hastanemiz mikrobiyoloji laboratuvarına çeşitli servis ve polikliniklerden bruselloz şüphesi ile gönderilen hasta serum örneklerinde çalışılan Rose Bengal ve Coombs aglütinasyon test sonuçlarının bölgemizdeki bruselloz seroprevalansı hakkında fikir vermesi amacıyla retrospektif olarak irdelenmesi amaçlanmıştır.

\section{YÖNTEM}

Bu çalışmada 2014-2018 yılları arasında Ordu Üniversitesi Tıp Fakültesi Hastanesi'ne başvuran hastalardan bruselloz şüphesiyle alınarak laboratuvarımıza gönderilen 2500 hastaya ait kan örneği sonuçları retrospektif olarak değerlendirilmiştir. Örnekler 3000 devirde 10 dakika santrifüj edilerek serumları ayrılmıştır. Brusella tanısı amacıyla
Rose Bengal tarama testi ile subakut veya kronik olgularda sıklıkla görülebilecek blokan antikorlar nedeniyle gelişebilecek yalancı negatifliklerin engellenmesi amacıyla laboratuarımızda rutin kullanılmakta olan Coombs aglütinasyon testi (CAT) kullanılmıştır. Rose-Bengal Testi için, standart anti-Brucella abortus serumla standardize edilmiş, B.abortus S99 (Pendik Veteriner Kontrol ve Araştırma Enstitüsü, İstanbul) ile hazırlanmış, Rose-Bengal boyası ile boyanmış ölü bakteri antijeni kullanılarak lateks aglütinasyon testi yapılmıştır. Karışım oda ısısında 4 dakika boyunca elle rotasyon hareketiyle çevrilerek herhangi bir aglütinasyon belirtisi olup olmadığına bakılmıştır. İri tanecikli çökeltiler olumlu, homojen görüntü ise olumsuz olarak değerlendirilmiştir. Coombs aglütinasyon testinde; tüpler 3000 rpm'de $10 \mathrm{dk}$ santrifüj edildikten sonra, üst kısımda kalan sıvı dökülerek serum fizyolojik eklenmiş ve tekrar $10 \mathrm{dk}$ santrifüj edilmiştir. Üç kez tekrarlanan işlem sonrasında tüplere anti-human globulin eklenerek 30 dakika etüvde bekletilmiş ve aglütinasyon gözlenen titreler pozitif olarak değerlendirilmiştir. Coombs aglütinasyon testi 1/20 titreden başlatılarak 1/1280 titreye kadar dilüsyonlar çalışılmıştır. Serumda 1/320 ve üzerinde Coombs pozitifliği bruselloz açısından anlamlı kabul edilmiştir. ${ }^{5}$ Çalışma için Ordu Üniversitesi Klinik Araştırmalar Etik Kurulundan onay alınmıştır (26/07/2018; 171). Bu çalışma Helsinki İlkeler Deklerasyonuna uyularak gerçekleştirilmiştir. Çalışmadan elde edilen verilen istatistiksel analizi, SPSS 22 (IBM, SPSS for Windows) programı kullanılarak yapılmıştır. Tanımlayıcı istatistiklerin sonuçları, sayı ve yüzde olarak verilmiştir.

\section{BULGULAR}

Bruselloz açısından 2500 serum örneği değerlendirilmiş olup 375 örnekte (\%15) Rose Bengal testi pozitif saptanmiştır. Coombs aglütinasyon testi ise 305 serum örneğinde $(\% 12,2) 1 / 320$ ve üzeri titrede pozitif bulunmuştur. Rose Bengal pozitif, Coombs aglütinasyon testi negatif 70 örnekten 10'unda aglütinasyon testi negatif iken kalan 60 örnekte değişen titrelerde ancak 1/320 altında sonuçlar elde edilmiştir. Doksan sekiz (\%39) olgunun Coombs ag- 
lütinasyon testi 1/1280 ve üzerinde saptanmıştır (Tablo 1). Örneklerin ve Coombs aglütinasyon testi pozitif olguların yıllara göre dağılımı Tablo 2'de belirtilmiştir. Olguların yaş ortalaması 49 olup \%34'ü kadın, \%66'sı erkek hasta; mevsimsel olarak ise en sık tanı ilkbahar aylarında saptanmıştır (Grafik 1).

\begin{tabular}{|l|c|c|c|c|c|c|c|c|}
\hline \multicolumn{7}{|l|}{ Tablo1: Rose-Bengal ve Coombs aglütinasyon testi sonuçları } \\
\hline $\begin{array}{l}\text { Serum } \\
\text { sayıs }\end{array}$ & 2125 & 10 & 20 & 25 & 15 & 126 & 81 & 98 \\
\hline $\begin{array}{l}\text { Rose } \\
\text { Bengal } \\
\text { testi }\end{array}$ & - & + & + & + & + & + & + & + \\
\hline $\begin{array}{l}\text { Coombs } \\
\text { aglütinasyon }\end{array}$ & - & - & $1 / 40$ & $1 / 80$ & $1 / 160$ & $1 / 320$ & $1 / 640$ & $1 / 1280$ \\
\hline
\end{tabular}

Tablo 2: Yıllara göre değerlendirilen Coombs aglütinasyon test pozitifliği

\begin{tabular}{|l|c|c|c|}
\hline Yıl & $\begin{array}{c}\text { Gelen örnek } \\
\text { sayısı }\end{array}$ & $\begin{array}{c}\text { Coombs } \\
\text { aglïtinasyon testi } \\
\text { pozitif örnek sayısı }\end{array}$ & Yüzde \% \\
\hline $\mathbf{2 0 1 4}$ & 195 & 19 & 9,74 \\
\hline $\mathbf{2 0 1 5}$ & 238 & 20 & 8,40 \\
\hline $\mathbf{2 0 1 6}$ & 552 & 35 & 6,30 \\
\hline $\mathbf{2 0 1 7}$ & 565 & 59 & 10,44 \\
\hline $\mathbf{2 0 1 8}$ & 950 & 172 & 18,00 \\
\hline
\end{tabular}

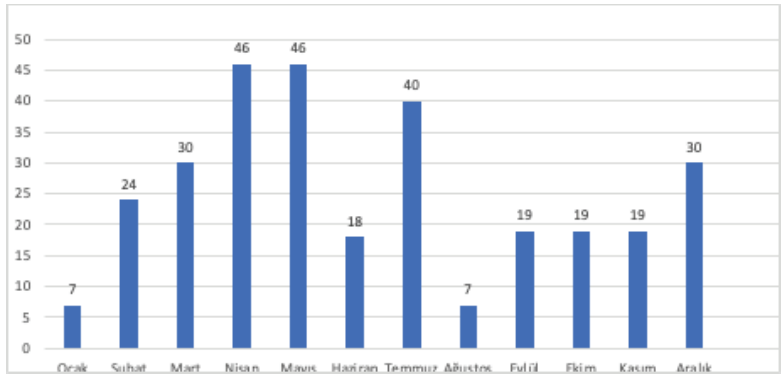

Grafik 1: Coombs aglütinasyon test pozitifliğinin gönderildiği aylara göre dağılımı

\section{TARTIŞMA}

Zoonozlar dünyada olduğu gibi ülkemizde de önemli halk sağlığı problemleri arasında yerini korumaktadır. Bruselloz ülkemizde zoonozlar içerisinde sık görülen hastalıklardan birisidir. İnsanlardaki hastalık sıklıkla hayvanlardaki, özellikle çiftlik hayvanlarındaki hastalık ile ilişkilidir. Dolayısıyla insanlarda bruselloz sıklığı hayvanlardaki sıklık ile paralellik gösterir. Hayvanlarda bruselloz, Avrupa ülkelerinde de görülmekle birlikte Akdeniz ülkeleri (Fransa, Portekiz, İspanya, Malta, Yunanistan ve Türkiye), Afrika, Asya ve Latin Amerika ülkeleri ve özellikle de Brezilya ve Meksika'da hastalık prevalansı yüksektir. İnsanlarda bruselloz tüm dünyada yaygın olmasına rağmen gerçek insidansı bilinmemektedir. Hastalığın insidansı ve prevalansı ülkeden ülkeye değişmektedir. ${ }^{6}$

Dean ve arkadaşlarının 2385 makaleyi değerlendirerek bruselloz sıklığını gözden geçirdikleri analizlerinde hem bölgesel hemde ülke içi farklı bölgelerde bile insidans raporlarının geniş bir varyasyon gösterdiği vurgulanmıştır.3 Örneğin Kuzey Afrika ve Orta Doğu bölgesinde 100,000 kişi/yıl olarak 52,3-268,8 aralığında değișen oranlar saptanmıştır. Bu çalışmada ülkemizdeki oranlar ise 100,000 kişi/yıl olarak 11,93- 49,54 arasında belirtilmiştir. Yumuk ve ark. ${ }^{4}$ Türkiye değerlendirmesinde 2000-2005 yılları arasinda kayıtlı 90.000 vaka bulunduğunu ancak gerçek rakamın bunun çok üzerinde olduğunu vurgulamıştır. Ülkemizde bildirilen geniş vaka sayılı çalışmalara göre; 1990'da Çetin ve arkadaşları farklı büyük şehirlerde (İstanbul, Ankara, Konya, Antalya, Diyarbakır, İzmir, Sivas, Erzurum ve Bursa) toplam 58707 sağlıklı bireyi ve 3734 mezbaha işçisini incelemiş ve aktif brusellozu sırasıyla \%1,8 ve \%6 olarak bulmuştur.7 Sağlıklı bireylerde en yüksek prevalans ise Diyarbakır'da, \%3,6 olarak saptanmıştır. 1991 ve 2005 yılları arasında yapılan diğer çalışmalarda Afyon (\%15,7), Malatya $(\% 2,9)$, Denizli $(\% 6,5)$, Kayseri $(\% 4)$, Bolu $(\% 1,3)$ ve Van $(\% 26,7)$ şeklinde seroprevalanslar bildirilmiştir.8-13 Afyon bölgesi süt örneklerinde yapılan bir çalışmada \%5 brusella antikor pozitifliği saptanmıştır. ${ }^{14}$ Bruselloz tanısı daha çok klinik ve serolojik bulgular ile konulmakta, ancak kesin tanı için etkenin kan veya diğer vücut sıvıları kültürlerinde üretilmesi gerekmektedir. Bakterinin yavaş üremesi, özel kültür koşulları gerektirmesi gibi nedenlerle serolojik yöntemler daha ön plana çıkmaktadır. Laboratuvara dayalı olarak bruselloz ön tanısı ile test istenerek yapılan değerlendirmeleri içeren çalışmalarda bruselloz sıklığı; İnönü Üniversitesi’nden Duman ve ark. ${ }^{15}$ tarafından 2012 
yılında $\% 5,5$, Yetkin ve ark. ${ }^{16}$ tarafindan Malatya ilinde \%7, İnci tarafından ${ }^{17}$ Artvin'de \%6, Orak tarafından ${ }^{18}$ Çorum'da \%21,09 olarak bildirilmiştir. Bizim çalışmamızda da değerlendirilen yıl aralıklarında pek çok ile göre daha yüksek oranlar saptanmıştır. Yıllık olarak hastalık sıklığı \%6,3-18 arasında izlenmiş ve özellikle 2018 yılında hem test isteminin hem de pozitif saptanan olgu sayısının artmış olması dikkat çekicidir. Bu sonucun farklı yakınmalar ile başvuran hasta gruplarında hekimlerin hastalık ile ilgili farkındalığının artması yönünde yorumlanabileceğini düşünmekteyiz.

Hastalık yılın tüm aylarında görülebilmekle birlikte, genellikle koyunların yavrulama dönemleri ile peynir yapımının arttığı ilkbahar ve yaz aylarında sıklı̆ğ artmaktadır. ${ }^{19,20}$ Gürsoy ve ark. ${ }^{21}$ çalışmalarında olguları en sık Mart, Ağustos ve Kasım aylarında, Mert ve ark. ${ }^{22} \% 74$ oranında yaz ve sonbahar aylarında görüldüğünü bildirmiştir. Uluğ ve ark. ${ }^{23}$ ise olguları $\% 83$ oranında yaz ve ilkbahar aylarında tespit etmiştir. Bizim değerlendirmemizde de olgular Nisan, Mayıs ve Temmuz aylarında pik yapmıștır.

\section{SONUÇ}

Özellikle hayvancılığın yoğun olduğu bölgelerde önemini koruyan bir zoonotik hastalık olan bruselloz ile ilgili ilimizden daha önce bildirilmiş bir oran söz konusu değildir. Sağlık Bakanlığı bildirim sistemine göre \%2,66 olarak kayıtlara geçmiş olmasına rağmen sonuçlarımız bunun çok üzerinde olduğunu göstermektedir. Klinik olarak çok farklı şekillerde karşımıza çıkabilecek bir hastalık olan brusellozun tanıda akılda tutulması gereken bir zoonotik hastalık olduğunu ve şüpheli hastalarda serolojik tetkiklerin yapılarak bildirim sistemleri ile daha sıkı takibinin uygun olacağını düşünmekteyiz.

\section{Maddi destek ve çıkar iliş̧kisi}

"Çalışmayı maddi olarak destekleyen kişi/kuruluş yoktur ve yazarların herhangi bir çıkar dayalı ilişkisi yoktur” 
J Biotechnol and Strategic Health Res. 2020;4(2):129-133

YILDIRIM, ÇETİNKOL, Ordu İli Bruselloz sıklığı

\section{Kaynaklar}

1. Sümerkan B. Brucella türleri. İnfeksiyon Hastalıkları ve Mikrobiyolojisi, Cilt 2. Topçu AW, Söyletir G, Doğanay M, (Ed), İstanbul. Nobel Tip Kitapevleri, 2002; s. 1647-52.

2. Young EJ. Brucellosis: current epidemiology, diagnosis and management. Curr Clin Top Infect Dis. 1995; 15: 115-28.

3. Dean AS, Crump L, Greter H, et al. Global burden of human brucellosis: a systematic review of disease frequency. PLoS Negl Trop Dis. 2012; 6(10): 1865.

4. Yumuk Z, O' Callaghan D. Brucellosis in Turkey an overview. Int J Infect Dis. 2012; 16(4): 228-35.

5. Ulusal Mikrobiyoloji Standartlarl: Brusellozun Mikrobiyolojik Tanısl. Ankara 2015;1-27.

6. Temel Sağlık Hizmetleri Genel Müdürlüğ̈̈ Zoonotik Hastalıklar Daire Başkanlığı. Zoonotik hastaliklar hizmet içi eğitim modülü. Bruselloz. Ankara: 2011;29-52

7. Cetin ET, Coral B, Bilgiy A, ve ark. Incidence of human brucellosis in Turkey. Doga Tr J Medical Sciences. 1990; 14: 324-34.

8. Cetinkaya Z, Aktepe OC, Ciftci IH, ve ark. Seroprevalence of human brucellosis in a rural area of Western Anatolia, Turkey. J Health Popul Nutr. 2005; 23: 137-41.

9. Cetinkaya F, Nacar M, Aydin T, ve ark. Prevalence of brucellosis in the rural area of Kayseri, Central Anatolia, Turkey. Int J Infect Dis. 2006; 10: 179-81.

10. Kose S, Smits HL, Abdoel TH, et al. Prevalence of Brucella antibodies in rural and suburban communities in three provinces of Turkey: need for improved diagnosis and prevention. J Infect. 2006; 53: 308-14.

11. Durmaz R, Durmaz B, Refik Mas M, ve ark. Seropositivity of brucellosis in Malatya, Turkey. Turk J Med Sci. 1997; 27: 125-28.

12. Kaleli I, Kocoglu T, Ozen N, ve ark. The prevalence of brucellosis in the Denizli region. Inf Derg. 1999; 13: 231-33.
13. Karabay O, Serin E, Tamer A, et al. Hepatitis B carriage and Brucella seroprevalence in urban and rural areas of Bolu province of Turkey: a prospective epidemiologic study. Turk J Gastroenterol. 2004; 15: 11-13.

14. Kenar B, Altındiș M. Afyon bölgesi süt örneklerinde Brusella antikoru araștırması. Türk Hij Den Biyol Derg. 2001; 58(3): 87-92

15. Duman Y, Tekerekoğlu MS, Batı NS, ve ark. İönü Üniversitesi Tip Fakültesi Hastanesinde Bruselloz Seroprevalanst: Rose Bengal, Wright, Coombs Aglütinasyon Test Sonuçlart. Medicine Science. 2013; 2(3): 679-88.

16. Yetkin G, Iraz M. Malatya ilinde bir ylllk sürede laboratuvar verilerine göre bruselloz seroprevalansi. ANKEM Derg. 2006; 20(3): 156-158.

17. İnci A. Artvin İlinde Laboratuar Verilerine Göre Bruselloz Sıklı̆ının Araștırılması. Clin Anal Med. 2015; 6(2): 183-85.

18. Orak F. Çorum İlinde Laboratuvar Verilerine Gore Bruselloz Seropozitifliği. Genel Tip Derg. 2016; 26(3): 69-73.

19. Tansel O, Yavuz M, Kuloğlu F, ve ark. Trakya Üniversitesi Hastanesine başvuran 40 bruselloz olgusunun değerlendirilmesi. İnfeks Derg. 2003; 17(1): 1-4.

20. Gur A, Geyik MF, Dikici B, et al. Complications of brucellosis in different age groups: A study of 283 cases in South eastern Anatolia of Turkey. Yonsei Med J. 2003; 44(1): 33-44.

21. Gursoy B, Tekin-Koruk S, Strmatel F, ve ark. Bruselloz: 140 olgunun değerlendirilmesi. Klimik Dergisi. 2008; 21(3): 101-04.

22. Mert A, Dumankar A, Tabak F, ve ark. Bruselloz: 38 olgunun değerlendirilmesi. Cerrahpașa Tip Fak Derg. 1996; 27: 204-11.

23. Uluğ M, Uluğ NC. Brusellozlu 78 Olgunun Değerlendirilmesi. Klimik Dergisi. 2010; 23(3): 89-94. 